\title{
ASSESSMENT OF EFFICIENCY OF REGENERATIVE HEATING SYSTEM OF FEED WATER FOR HIGH TEMPERATURE TURBINE PLANT ON DECENTRALIZED POWER ENGINEERING FACILITIES
}

\author{
Kirill Larionov ${ }^{1}$, a , Dmitrij Gvozdjakov ${ }^{1}$, Andrej Zenkov ${ }^{1}$, Vladimir Zaytsev ${ }^{1}$ \\ ${ }^{1}$ National Research Tomsk Polytechnic University, 634050 Tomsk, Russia
}

\begin{abstract}
The results of theoretical researches on efficiency of air heater use have been presented. The results of the research show the possibility of increase of energy efficiency of electrical power unit on electrical energy consumption by $2 \%$ at the initial temperature of steam $1073 \mathrm{~K}$. The possibility of decrease of unit consumption of reference fuel by $4 \%$ has been stated.
\end{abstract}

\section{Introduction}

Rapid increase of energy consumption in the world for the last decade is accompanied with putting into operation energy complexes and development of new raw hydrocarbon deposits [1]. Absence of centralized power supply at some areas is the main reason of creation of autonomous power sources with high efficiency equipment [2]. It is known [3] that the main requirement to such facilities is production of energy with high energy efficiency coefficient $50 \%$ and more [4]. Today only modern steam and gas plants with temperatures at the entrance into gas turbine 1673-1873 $K$ match these energy efficiency requirements [5].

It is known [6] that works on initial parameters of steam turbine plants increase are done abroad and in Russia [7, 8]. Today experimental industrial samples with initial steam temperature $1073 K$ [9] have been made and positive results after first approbations have been achieved [10].

According to [11], a great increase of energy efficiency of high temperature turbine plants, work of regenerative heating system of feed water is more effective at initial low temperatures of steam.

The purpose of the work is theoretical researches on efficiency increase of electrical power unit with steam turbine plant with electrical power $200 \mathrm{MWt}$ made in Russia for distant regions not included into total electric power system.

\section{Problem setting}

\footnotetext{
${ }^{a}$ Corresponding author: laryk070@gmail.com
} 
Assessment of efficiency increase of steam turbine plant with initial temperature and temperature in steam superheater $800^{\circ} \mathrm{C}$ was made on turbine plant $\mathrm{K}-200-130$. The initial parameters of the presented turbine plant have initial temperature $838 \mathrm{~K}$ and pressure $13 \mathrm{MPa}$ and pressure in condenser $0.0033 \mathrm{MPa}$ [12]. 4 and 3 heaters of low and high pressure were taken into account at design of initial diagram of regenerative heating of feed water (fig. 1).

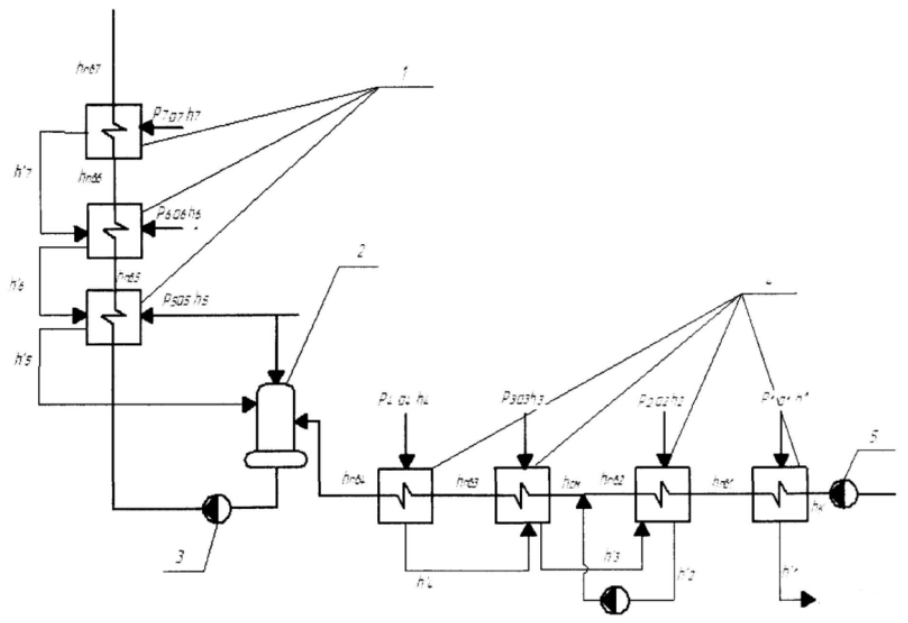

Figure 1. Principal diagram of regenerative heating of feed water (1- high pressure heaters, 2 - diaerator, 3 feeding pump, 4 - low pressure heaters, 5 - condensation pump).

Initial researches showed that increase of steam parameters (temperature) enables power increase of electrical power unit up to $273 \mathrm{MWt}$. The result of it is increase of absolute electrical energy efficiency by $4.3 \%$ which made $48.5 \%$. Besides energy efficiency of plant of energy consumption increased by $3.8 \%$ which led to decrease of unit consumption of reference fuel by $8.8 \%$. Below in table 1 are initial data for designs.

Table 1. Parameters of steam at different initial temperatures.

\begin{tabular}{|c|c|c|c|c|c|}
\hline \multirow{3}{*}{$\begin{array}{l}\text { Selection/Heat } \\
\text { exchanger }\end{array}$} & \multirow{3}{*}{$\begin{array}{c}\text { Steam pressure, } \\
\mathrm{MPa}\end{array}$} & \multirow{3}{*}{$\begin{array}{c}\text { Enthalpy of } \\
\text { drainages } \mathrm{h}_{\mathrm{i}}^{\prime} \text {, } \\
\mathrm{kJ} / \mathrm{kg}\end{array}$} & \multirow{3}{*}{$\begin{array}{l}\text { Enthalpy of feed } \\
\text { water } h_{i}{ }^{f w}, k J / k g\end{array}$} & \multicolumn{2}{|c|}{ Steam temperature, $K$} \\
\hline & & & & 838 & 1073 \\
\hline & & & & \multicolumn{2}{|c|}{$\begin{array}{c}\text { Enthalpy of steam } \mathrm{h}_{\mathrm{i}}^{\prime}, \\
\mathrm{kJ} / \mathrm{kg}\end{array}$} \\
\hline 0 & 12.11 & - & - & 3516 & 4105 \\
\hline 7 & 3.36 & 1005 & 1018 & 3210 & 3618 \\
\hline 6 & 2.28 & 919 & 919 & 3115 & 3503 \\
\hline $\begin{array}{c}\text { SS (steam } \\
\text { superheater) }\end{array}$ & 2.06 & - & - & 3612 & 4152 \\
\hline 5 & 1.04 & 634 & 749 & 3427 & 3948 \\
\hline 4 & 0.55 & 651 & 634 & 3251 & 3730 \\
\hline 3 & 0.24 & 526 & 507 & 3050 & 3496 \\
\hline 2 & 0.11 & 418 & 416 & 2891 & 3004 \\
\hline 1 & 0.02 & 263 & 241 & 2640 & 2992 \\
\hline Condenser & 0.003 & - & 108 & 2430 & 2651 \\
\hline
\end{tabular}

It is known [13] that steam initial temperature increase causes decrease of quantity of selected steam fro feed water heating the result of which is decrease of regeneration system efficiency. 
Accordingly it was offered to include additional surfaces of heating into this diagram in the form of air heaters (pic. 2).

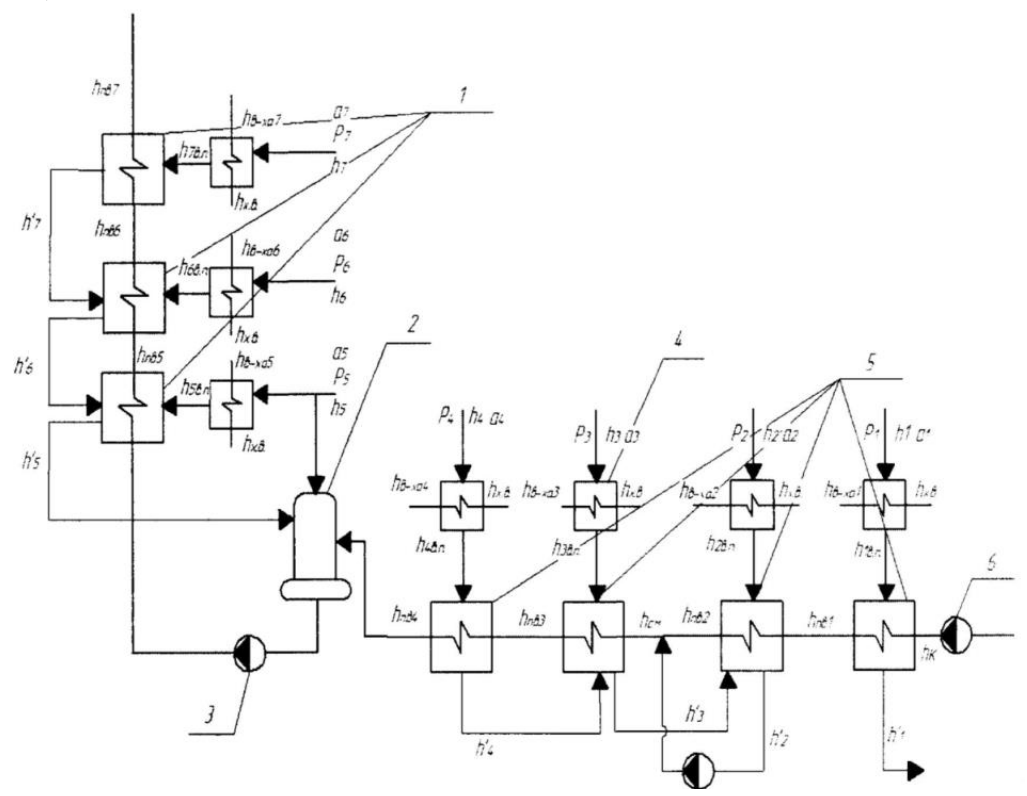

Figure 2. Principal diagram of regenerative heating of feed water with air heaters $(1-$ high pressure heaters, $2-$ diaerator, 3 - feeding pump, 4 - air heater, 5 - low pressure heaters, 6 - condensation pump).

According to the diagram (fig. 2) air heater was set as a single heat exchanging plant before each regenerative heater on the line of steam selection. After heating air with steam its flows are mixed and go into steam boiler. The main purpose of including additional air heating surfaces into feed water heating regenerative diagram is temperature decrease of extracted overheated steam from turbines which is $283 \ldots 288 \mathrm{~K}$ higher than the condition of aeration and decrease of given quantity of heat $\mathrm{Q}_{0}$ by means of temperature increase of air given into steam boiler.

Design of quantity of heat connected to turbine plant $\mathrm{Q}_{0}$, of useful heat given to air by steam $\mathrm{Q}_{\text {air }}$, electrical power $\mathrm{N}_{\mathrm{e}}$, absolute electrical energy efficiency $\eta_{e}$, plant energy efficiency of energy consumption and unit consumption of reference fuel is done in accordance with well-known formulas [13]:

$$
\begin{gathered}
\mathrm{Q}_{0}=\mathrm{D}_{0} \cdot\left(\mathrm{h}_{0}-\mathrm{h}_{7}^{\mathrm{fw}}\right)+\left(\mathrm{D}_{0}-\mathrm{D}_{7}-\mathrm{D}_{6}\right) \cdot\left(\mathrm{h}_{\mathrm{oh}}-\mathrm{h}_{6}\right), \mathrm{MJ} \\
\mathrm{Q}_{\mathrm{air}}=\sum \mathrm{D}_{\mathrm{i}} \cdot\left(\mathrm{h}_{\mathrm{i}}-\mathrm{h}_{\mathrm{i}}^{\mathrm{fw}}\right), \mathrm{MJ} . \\
\mathrm{N}_{\mathrm{e}}=\mathrm{D}_{0} \cdot \mathrm{H}_{\mathrm{i}} \cdot\left(1-\sum \alpha_{\mathrm{i}} \cdot \mathrm{y}_{\mathrm{i}}\right) \cdot \mathrm{\eta}_{\mathrm{m}} \cdot \mathrm{\eta}_{\mathrm{g}}, \mathrm{MWt} \\
\eta_{\mathrm{e}}=\frac{\mathrm{N}_{\mathrm{e}}}{\mathrm{Q}_{0}-\mathrm{Q}_{\mathrm{air}}}, \% . \\
\mathrm{\eta}_{\mathrm{st}}^{\ni}=\mathrm{\eta}_{\mathrm{m}} \cdot \mathrm{\eta}_{\mathrm{g}} \cdot \mathrm{\eta}_{\mathrm{kst}} \cdot\left(1-\mathrm{k}_{\mathrm{hn}}\right), \% \\
\mathrm{~b}_{\mathrm{st}}^{\ni}=\frac{123}{\mathrm{\eta}_{\mathrm{st}}^{3}}, \mathrm{GCE} /(\mathrm{kWt} \cdot \mathrm{h}) .1
\end{gathered}
$$

where $\mathrm{y}_{1}$ - underproduction power coefficient; $\eta_{\text {airheater }}$ and $\eta_{\text {feedwater }}-$ energy efficiency of air heaters and feed water taken as $98 \% ; \mathrm{h}_{\mathrm{i}}^{\text {air }}$ - enthalpy of air according to [14]; $\mathrm{H}_{\mathrm{i}}-$ actual heat drop of turbine plant; $\eta_{\mathrm{m}}, \eta_{\mathrm{g}}-$ mechanical and generator energy efficiency taken as $99 \% ; \eta_{\mathrm{p}}$ - losses of heat in pipeline equal to $1 \% ; \eta_{\mathrm{kst}}$ - energy efficiency of steam source equal to $95 \% ; \mathrm{k}_{\mathrm{nh}}$ - unit consumption of electrical energy for in-house needs, equal to 0.05 [13]. 
It should be noted that within the problem set in this work theoretical researches were done with initial change of steam temperature at constant settings of steam pressure in relation to thermodynamic efficiency.

\section{Results and their discussion}

The results of the theoretical researches for assessment of efficiency of feed water regenerative heating with air heaters are in table 2.

Table 2. Data of electric power unit efficiency.

\begin{tabular}{|c|c|c|}
\hline \multirow{2}{*}{ Name of parameter } & \multicolumn{2}{|c|}{ Steam temperature, $\mathrm{K}$} \\
\hline & 838 & 1073 \\
\hline Turbine plant power $\mathrm{N}_{\mathrm{e}}, \mathrm{MWt}$ & 192.5 & 264.2 \\
\hline Quantity of given heat $\mathrm{Q}_{0}, \mathrm{MJ}$ & 450.3 & 561.0 \\
\hline Quality of heat given to air from steam $\mathrm{Q}_{\text {air }}, \mathrm{MJ}$ & 17.6 & 38.4 \\
\hline Absolute electrical energy efficiency $\eta_{\mathrm{e}}$ of turbine plant, $\%$ & 44.5 & 50.5 \\
\hline Electrical power plant energy efficiency (net), $\%$ & 39.8 & 45.3 \\
\hline $\begin{array}{l}\text { Unit consumption of reference fuel of energy consumption, } \\
\qquad \mathrm{GCE} /(\mathrm{kWt} \cdot \mathrm{h})\end{array}$ & 309.0 & 272.7 \\
\hline
\end{tabular}

There is a small decrease of electrical power $\mathrm{N}_{\mathrm{e}}$ as a result of including additional heating surfaces of air before regenerative heaters, which is connected with increase of steam consumption in turbine selectors for air heating needs. Despite turbine plant power decrease for design initial steam temperature $1073 K$ there is increase of absolute electrical energy efficiency and energy efficiency of energy consumption by $2 \%$ which led to decrease of unit consumption of reference fuel by $4 \%$. This effect was caused by useful quantity of heat put into steam boiler with heated air which decreases quantity of heat connected to turbine plant and fuel consumption.

It should be noted that absolute electrical energy efficiency of turbine plant was almost unchanged and increased by $0.3 \%$ at initial steam temperature $838 \mathrm{~K}$. This proves that use of air heaters in feed water regenerative heating diagram is purposeful only for initial high temperatures which energetic potential can be effectively used for thermodynamic cycle energy efficiency increase.

\section{Conclusion}

Theoretical researches of high temperature turbine plant showed that increase of steam initial temperature causes increase of energy efficiency of energy consumption by $3.8 \%$ and decrease of unit consumption of reference fuel by $8.8 \%$. Accordingly feed water regenerative heating system efficiency decreases because of increase of steam temperature in turbine selectors which leads to decrease of the quantity of selected steam for feed water heating going into steam boiler.

When including additional heating surfaces in the form of air heaters in design initial steam temperature $1073 \mathrm{~K}$ into feed water heating regenerative system there is decrease of electrical power with increase of plant energy efficiency of energy consumption by $2 \%$ and the result of it is decrease of unit consumption of reference fuel by $4 \%$.

Decrease of power was caused by increase of steam consumption from turbine selectors on production needs of additional heat going into steam boiler by means of which plant energy efficiency increases. A small increase of plant energy efficiency by $0.3 \%$ can be explained by the fact that at analyzed temperatures and constant consumption steam does not have high energetic potential able to transmit the sufficient quantity of heat to air directed into steam boiler to increase efficiency of thermodynamic cycle of turbine plant. 
The results in this work allow making a conclusion about the efficiency of the above-mentioned diagram and possibility of its application at power engineering facilities situated in far regions without total electric power system.

The work has been done in framework of federal focused program implementation "Competitiveness Enhancement Program" of National Research Tomsk Polytechnic University.

\section{References}

1. V. Dmitrienko, B. Lukutin, Modern problems of science and education, 3, 1 (2014)

2. S. Tihonov, A. Il'in, Ju. Luk'janov, Bulletin of the Pskov State University, 2, 199 (2013)

3. N. Galashov, S. Tsibulskiy, Power Technology and Engineering : Scientific Journal, 48, (2015)

4. A. Salamov, Energy abroad, № 1 (2009).

5. N. Galashov, S. Cibul'skij, Bulletin TPU, 325 (4), 33 (2014).

6. S. Ivanov, K. Tsvetkov, Power stations, (2), 50 (2015).

7. A. Tumanovskij, V. Kotler, Energy facilities abroad, (3) (2007).

8. E. Somova, A. Shvarc, Je. Verboveckij, Energetic, (2), 39 (2015)

9. A. Zarjankin, A. Rogalev, G. Sojko, Intense and technical sciences, (5), (2013).

10. S. Imano, N. Sato, H. Kamoshida, Development and trial manufacturing of Ni-base alloys for coal fired power plant with temperature capability $800^{\circ} \mathrm{C}$ (Advances in Materials Technology for Fossil Power Plants, Proceedings from the 7th International Conference, 2014)

11. O. Favorskij, A. Mil'man, V. Fedorov, O. Milman, Energy-efficient continuous proizvodstvo ispolzlvaniem electricity with combined organic and hydrogen fuel, (the International Forum Hydrogen Technologies for Energy Production), (2006)

12. A. Kostjuk, V. Frolov, A. Bulkin, A. Truhnij, The turbines of thermal and nuclear power plants (MJeI, 2001)

13. S. Sterman, V. Lavygin, S. Tishin, Thermal and nuclear power stations: the textbook for students, (MJeI, 2008).

14. S. Rivkin, Thermodynamic properties of gases, (Energoatomizdat, 1987) 